\title{
ACQUIRED LIP DEFECTS; SURGICAL MANAGEMENT
}

1. FCPS (Plastic Surgery) Assistant Professor Plastic Surgery Shaikh Zayed Postgraduate Medical Institute, Lahore

Correspondence Address: Dr. Muhammad Ali Rafique Mirza FCPS (Plastic Surgery) Assistant Professor Plastic Surgery Shaikh Zayed Postgraduate Medical Institute, Lahore draliszh@hotmail.com

Article received on: 08/03/2016

Accepted for publication: 10/04/2016

Received after proof reading: 04/05/2016

\section{Dr. Muhammad Ali Rafique Mirza}

ABSTRACT... Objectives: To evaluate the functional outcome of large acquired lip defects requiring flap reconstruction. Study design: Descriptive study. Setting: Shaikh Zayed Postgraduate Medical Institute, Lahore. Period: January, 2011 to December, 2014. Methodology: Large lip defects secondary to benign or malignant tumors which could not be closed primarily or involving more than one tissue layer were included. Patients with history of trauma or thermal injuries were excluded. Results: Twelve patients were included in the study. Mean age group was 57.4 years (34 to 75); male to female ratio 1.4: 1; oral commissure tissue deficiency (5 cases) was corrected with cheek advancement and rotation flaps; upper lip defects (3 cases) were reconstructed with cheek advancement and lip switch flaps; for lower lip repair (4 cases), Karapandzic flaps were the primary flaps utilized. Overall complication rate was $16.6 \%$. Partial wound dehiscence was seen in one patient (8.3\%). Significant microstomia requiring surgical correction was experienced in one patient. Conclusion: Lip reconstruction of acquired defects can be achieved with good functional results by proper planning and judicious use of remaining lip and local cheek tissue.

Key words: $\quad$ Lip Reconstruction, Lower Lip, Upper Lip, Oral Commissure

Article Citation: Mirza MAR. Acquired lip defects; surgical management. Professional Med $\mathrm{J}$ 2016;23(5):522-525. DOI: 10.17957/TPMJ/16.3330

\section{INTRODUCTION}

Lips constitute the lower third of the face and are very important functional and aesthetic organs. Lips play very important role in digestion by sealing the oral stoma and allowing food to role and compress against the bony skeleton. Lips participate in both verbal and nonverbal communication. Articulation, the physical production of speech sound, is modified by lip movement. Lip position, shape and motion are gestures used to express emotions. ${ }^{1}$ Most common cause of acquired lip defects in adults is malignancy followed by burns and trauma. Various options for reconstruction are available for the reconstruction of lip defects depending on the size, site, type of skin involved and the condition of adjoining structures. Upper lip defects cause more aesthetic disfigurement while the lower lip defects create functional morbidity like drooling and oral incompetence. Defects involving the oral commissure are technically more demanding. We present our experience of repair of acquired lip defects at Shaikh Zayed PGMI, Lahore.

\section{MATERIAL AND METHODS}

The study was done during Jan, 2011 to Dec. 2014. Patients with tumors involving lips, whether benign or malignant, which could not be closed primarily or required repairs of more than one layer were included in the study. Patients with history of trauma or thermal injury were excluded from the study. The patients were admitted through Out Patient Department. Relevant investigations were carried out. Elective surgery was performed either under general anesthesia or local anesthesia depending on the age, fitness for anesthesia and type of reconstruction required. Patients were followed postoperatively at first and 6th day and one month interval for adequacy of repair and the functional outcome.

\section{RESULTS}

A total of 12 patients were included in the study. There were 7 males (58.3\%) and 5 females $(41.7 \%)$. Mean age was 57.4 years (34 to 75 ). Reconstruction was carried out after getting margin and depth clearance of the excised tissue. Upper lip repair was achieved with lip cheek 
vermillion advancement, or lip switch and cheek advancement. Oral commissure was involved in 5 patients, lower lip in 4 and upper lip in 3 patients (Graph-1). Either cheek advancement alone or advancement with rotation or lip switch was required for commissure repair. Lower lip defects were repaired with Karapandzic Flaps alone even for total lower lip loss. Except one patient where only the skin and orbicularis oris muscle were excised, all the layers of lips (skin, muscle and mucosa) required reconstruction (91.7\%). Patency of oral sulcus was maintained in all the patients. There was no fistula formation. Only one patient developed microstomia significant enough to require secondary surgery (Table-I).

\section{Lip segment involvement}

mOral Commisure $=$ Lower lip $=$ Upper lip

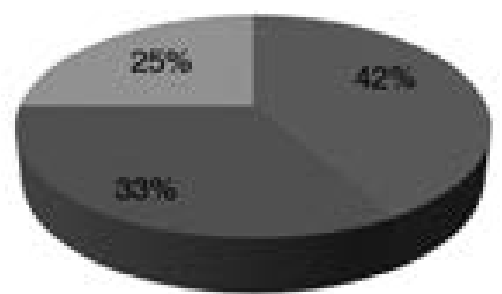

Graph-1. Lip segment involvement

\begin{tabular}{|c|c|c|c|c|c|c|c|}
\hline $\begin{array}{l}\text { Case } \\
\text { no. }\end{array}$ & $\begin{array}{l}\text { Age/ } \\
\text { sex }\end{array}$ & $\begin{array}{l}\text { Lip segment } \\
\text { involved }\end{array}$ & Size of defect & $\begin{array}{l}\text { Reconstructive } \\
\text { procedure }\end{array}$ & $\begin{array}{l}\text { Wound } \\
\text { problems }\end{array}$ & $\begin{array}{c}\text { Oral } \\
\text { competence }\end{array}$ & Microstomia \\
\hline 1. & $55 / F$ & Lower lip & $80 \%$ & Karapandzic flap & Nil & Adequate & No \\
\hline 2. & $58 / \mathrm{M}$ & $\begin{array}{c}\text { Oral } \\
\text { commissure }\end{array}$ & $\begin{array}{l}\text { Upper lip } 10 \% \text {; } \\
\text { lower lip } 25 \%\end{array}$ & $\begin{array}{l}\text { Cheek advancement } \\
\text { + lower lip switch }\end{array}$ & Nil & Adequate & No \\
\hline 3. & $62 / M$ & $\begin{array}{c}\text { Oral } \\
\text { commissure }\end{array}$ & Both lips & $\begin{array}{c}\text { Cheek advancement } \\
\text { + rotation }\end{array}$ & Nil & Adequate & No \\
\hline 4. & $55 / F$ & Lower lip & $100 \%$ & B/L Karapandzic & Nil & Adequate & No \\
\hline 5. & $75 / F$ & $\begin{array}{c}\text { Oral } \\
\text { commissure }\end{array}$ & $\begin{array}{l}\text { Upper lip 50\%; } \\
\text { lower lip 10\% }\end{array}$ & Cheek advancement & Nil & Adequate & No \\
\hline 6. & $60 / F$ & Upper lip & $50 \%$ & $\begin{array}{l}\text { Lip/cheek } \\
\text { advancement }\end{array}$ & Nil & Adequate & No \\
\hline 7. & $60 / M$ & Upper lip & $75 \%$ & Lip switch & Nil & Adequate & $\begin{array}{l}\text { Yes ( patient } \\
\text { required revision } \\
\text { surgery }\end{array}$ \\
\hline 8. & $34 / \mathrm{M}$ & $\begin{array}{c}\text { Oral } \\
\text { commissure }\end{array}$ & $\begin{array}{l}\text { Upper lip 50\%; } \\
\text { lower lip 10\% }\end{array}$ & $\begin{array}{l}\text { Lip switch \& modified } \\
\text { Karapandzic flap }\end{array}$ & Nil & Adequate & No \\
\hline 9. & $50 / F$ & Lower lip & $85 \%$ & B/L Karapandzic & Nil & Adequate & No \\
\hline 10. & $60 / M$ & $\begin{array}{c}\text { Oral } \\
\text { commissure }\end{array}$ & $\begin{array}{l}\text { Upper lip 50\%; } \\
\text { lower lip 5\% }\end{array}$ & Cheek advancement & $\begin{array}{l}\text { Partial dehiscence; } \\
\text { healed with } \\
\text { secondary intention }\end{array}$ & Adequate & No \\
\hline 11. & $55 / \mathrm{M}$ & Upper lip & $40 \%$ & $\begin{array}{l}\text { Lip and cheek } \\
\text { advancement }\end{array}$ & Nil & Adequate & No \\
\hline 12. & $65 / M$ & Lower lip & $85 \%$ & B/L Karapandzic & Nil & Adequate & No \\
\hline
\end{tabular}

Table-I. Age/sex of patients; size of defects; reconstructive procedures used and outcome;

\section{DISCUSSION}

Lip reconstruction is challenging from both functional and aesthetic point of view. Aesthetic and reconstructive skills are required for optimal functional results. The principle of like for like should be followed whenever possible. ${ }^{2}$ Functional restoration, specially maintaining the sphincter patency, prevention of drooling of saliva, adequate mouth opening to achieve oral hygiene and feeding and preservation of sensation are the main goals of lip reconstruction. ${ }^{3}$ Choices for reconstruction in descending order of preference are tissues from the remaining lip, the opposite lip (lip switch), adjacent cheek, distant flaps and free tissue transfer. ${ }^{4}$

Upper lip defects measuring more than one third of lip can be repaired with medial cheek advancement and/or lip switch flap. The lines of cheek advancement flaps can be designed to camouflage in the cheek aesthetic units (Figure-1). In the present study, good aesthetic results were 

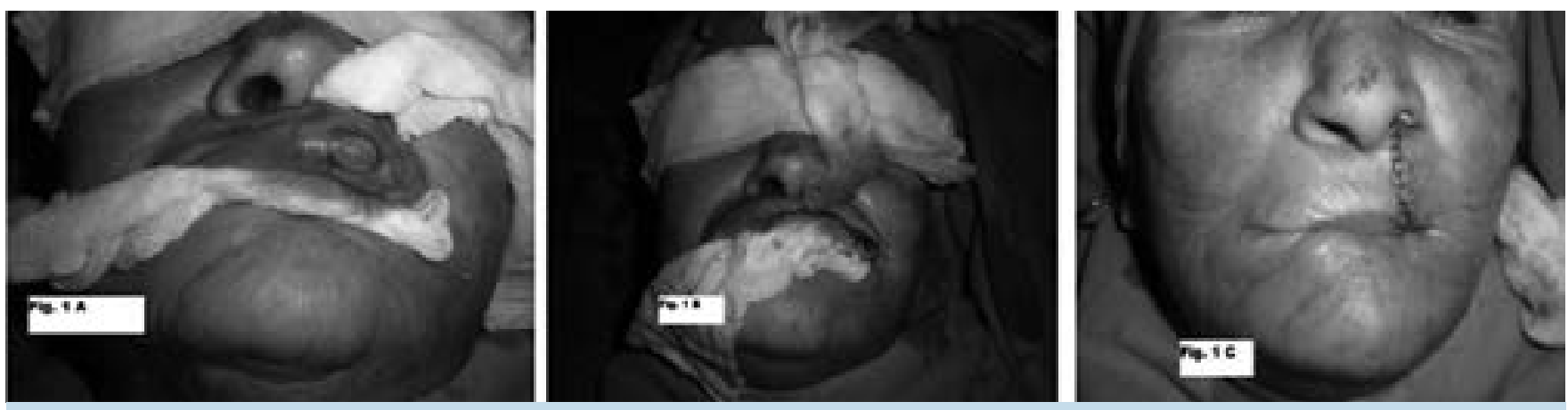

Figure-1. A 60 year's old lady (case 6) with squamous cell carcinoma of left side of upper lip (Figure-1 A). Post excision $50 \%$ defect (Fig-1 B) reconstructed with lip and cheek advancement flap (Figure-1 C).
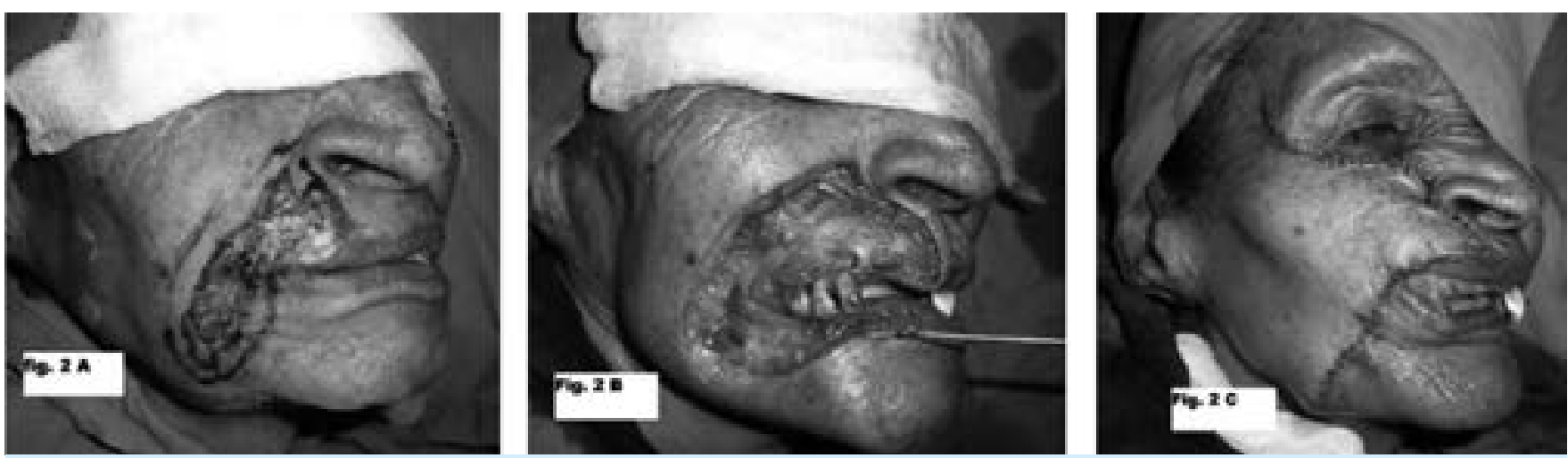

Figure-2. 75 year's female (case 5) with squamous cell carcinoma involving oral commissure (Figure-2 A). Defect after excision of tumor (Figure-2 B). Reconstruction with cheek advancement flap Figure-2 C).

achieved with cheek advancement flaps in all the patients and no revision surgery was required. In a study carried out by Graffin ${ }^{5}$, revision surgery was performed in $47 \%$ cases. The reason was location of lip defects involving ala of nose and lip vermillion requiring improvement of the residual scars and relatively young patients. Severe microstomia developed in one patient, in which cheek advancement and lip switch flaps were done simultaneously to repair the upper lip segment.

Reconstruction of oral commissure is difficult because not only both lips are involved but the adjacent cheek and oral mucosa may also need excision due to extension of tumor pathology, reducing the amount of adjacent tissues for repair. Different operative techniques like a medially based rotation-advancement flap from the upper to lower lip, a reverse Estlander can be performed ${ }^{6}$ by rotating a lower lip segment to a lateral upper lip or commissure: and Gilies fan flaps. ${ }^{2}$ In the present study, cheek advancement and rotation flaps were used for lip repair with satisfactory results (Figure-2). One patient developed wound dehiscence which healed spontaneously without surgical intervention. For lower lip defects, the Karapandzic's flap was used. This technique for large defects of the lip, involves unilateral or bilateral full-thickness circum-oral advancement-rotation flaps. ${ }^{7}$ The key feature of this reconstruction technique is preserving the neural and vascular structures that are encountered in the plane of dissection, so that optimal oral competence and sensory functions are preserved. The releasing incisions of this orbicularis oris musculocutaneous flap are placed around the periphery of the anatomic lip unit and should be masked within the labio-mental and melolabial creases. Incidence of microstomia has been reported to be $17 \%{ }^{8}$ and $23.5 \%{ }^{9}$ with Karapandzic flap. Reconstruction of $100 \%$ lower lip defect (Figure-3) was achieved without any adverse sequelae in. In our experience bilateral Karapandzic flaps provide sufficient tissue for lower lip repair with good functional and aesthetic results. 

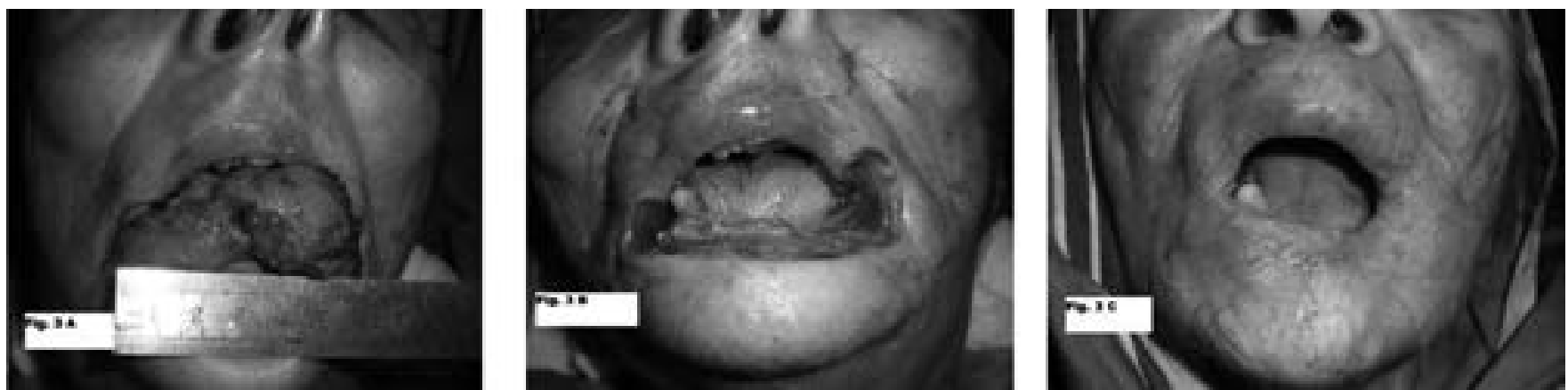

Fig. 3. A 65 years old female with, squamous cell carcinoma involving lower lip (Fig 3 A); 100\% lower lip defect (Fig 3

B) reconstructed with bilateral Karapandzic Flaps. Adequate mouth opening (Fig. 3 C) at one month follow up.

\section{CONCLUSION}

Reconstruction of large acquired lip defects can be achieved with proper planning and judicious use of remaining lip and local cheek tissue. Patients should be evaluated and treated according to their functional requirements and available tissue for best results.

\section{Copyright(C) 10 Apr, 2016.}

\section{REFERENCES}

1. Matros E.; Pribaz J. J.; Grabb and Smith's Plastic Surgery; Lippincott \& Wilkins, Philadelphia; $7^{\text {th }}$ Ed.; 2014; 372-383.

2. Gillies H, Millard D R J R. Lip Trauma. In: The Principles and Art of Plastic Surgery. Boston: Little Brown 1957; 496-519.

3. Fewkes JL, Cheney ML, Pollack SV. Lip reconstruction. In: Illustrated atlas of cutaneous surgery. Lippincott1992. 32.1-32.13.

4. Luce E A. Reconstruction of the lower lip. Clin Plast
Surg 1995; 22: 109-21.

5. Griffin R. G.; Weber S.; Baker S. R.; Outcomes following V-Y Advancement Flap Reconstruction of Large Upper Lip Defects. Arch Facial Plast Surg. 2012; 14(3):193-197.

6. Sundell: B. The classic reprint translation of - fine Medaode aut der Eincn Lippe Substannerlutte der Anden:n Zu Enetzen •, by JA Etdander. Pluth carutr SIIrf. 1968; $42: 7$.

7. Karapandzic M. Reconstruction of lip defects by local arterial flaps. Br J Plast Surg 1974; 27: 93-97.

8. Memon A. R.; Tahir S. M, Shaikh B. F, Outcome of Reconstruction of Lower Lip Squamous Cell Carcinoma in Different Treatment Modalities. Pakistan Journal of Surgery; 2008; 4: 261-265.

9. Riffat M. A. Lower lip Reconstruction after Tumor Resection; A single Author's Experience with Various Methods. Journal of Egyptian Nat. Cancer Inst., 2006; 18(4): 323-333.

\section{AUTHORSHIP AND CONTRIBUTION DECLARATION}

\begin{tabular}{|c|c|l|l|}
\hline Sr. \# & Author-s Full Name & Contribution to the paper & Author=s Signature \\
1 & Dr. Muhammad Ali Rafique Mirza & $\begin{array}{l}\text { Principle author, } \\
\text { Research work and } \\
\text { data writing share its } \\
\text { expert research opinion }\end{array}$
\end{tabular}

